\title{
Opportunities Provided by Big Data Technology for Government Management*
}

\author{
Jian Ping \\ Department of Public Administration Teaching and Research \\ Liaoning Provincial Party School of the Communist Party of China \\ Shenyang, China 110004
}

\begin{abstract}
For government management, the application of big data has brought tremendous changes to public management and public services, and also provided a feasible path for innovation and improvement of capacity of government management. On the basis of summarizing the concept and characteristics of big data, this paper teases out the development history of big data at home and abroad, and analyzes the opportunities brought by big data technology for government management from the perspectives of information disclosure, fine service and precise decision-making.
\end{abstract}

\section{Keywords - big data; government management; opportunities}

\section{INTRODUCTION}

With the rapid advancement of the information revolution, information production and processing methods have continued to develop, and the information process of the whole society has been accelerated, which causes major changes in economic and social productivity and production relations. In 2012, the report of World Economic Forum in Davos, Switzerland pointed out that big data, like currency or gold, had become a new economic asset. The former American President Obama has described big data as a kind of new oil in the future world, which shows the strategic position and importance of big data technology. Big data is profoundly changing people's production, life and thinking modes. The research, development and application of big data technology have become the focus of attention from all walks of life. For government management, the application of big data has brought great changes to public management and public service, and provided a technical path for innovation and improvement of capacity of government management. The full development and utilization of big data technology can greatly improve the efficiency and effectiveness of government management, further lower the operation cost of the government, and improve governmental society governance capability in an all-round way.

\section{THE CONCEPT AND CHARACTERISTICS OF BIG DATA}

Different scholars have elaborated on the concept of big data from various angles. Wikipedia defines big data as: "Big

*Fund Program: Youth Fund Project of Humanities and Social Sciences Research of the Ministry of National Education (16YJCZH159); the Social Science Planning Funds for Liaoning (Grant NO. L16CGL016)

Chinese Library Classification Number: D630 Document Code: A. data is a data set that cannot be disposed, processed, and managed by common software." Schoenberg, a famous scholar, believed that: "big data is comprehensive data, and not a stochastic analysis method such as sampling survey"[1]. In 2015, China gave the definition of big data in Action Outline for Promoting Big Data Development: "big data is a data set characterized by large volume, varieties, fast access velocity, and high application value". The English initial of the four features mentioned in this definition are all $\mathrm{V}$, so the industry also refers to these four features as $4 \mathrm{~V}$ features. The first is large volume. In 2010, the total data owned by humans reached the $\mathrm{ZB}$ level, about $1.2 \mathrm{ZB}$. If the data are burned to DVD discs, these discs can be laid back and forth between the Earth and the Moon. The data volume is still growing rapidly. In 2016, Google processed 6.95 million search requests per minute. It is predicted that "the total data owned by humans will exceed 40ZB in 2020". The second is varieties. Big data includes three types: structured data represented by numbers, unstructured data represented by office documents, text, pictures, audio and video, and semi-structured data represented by HTML documents. The third is high value. In business, enterprises can analyze consumer behavior, evaluate consumers' credibility and avoid potential risks through big data. In government management, by means of big data, we can realize intelligent management in the fields of transportation, medical care and agriculture[2], and can also assist the government to make decisions, to achieve the innovation of government management. The fourth is fast access velocity. Data value has timeliness, so fast access to useful information is the key feature of big data in a mass of data.

\section{The DEVELOPMENT OF BIG DATA}

In 1980, the famous American scholar Alvin Toffler wrote a book named The Third Wave, first mentioned the word "big data", and called it colorful movement of the third wave. Gary King, a Harvard professor, described big data as a revolution, and the process of data quantification will be started in government, business and other various fields. Well-known consulting firm McKinsey \& Company believes that the application and development of big data indicates the arrival of a new wave of productivity growth. Although the term big data has been mentioned very early, its application value has not been recognized by the industry. Until the end of 2008, the United States information technology authoritative 
organization, Computer Community Consortium (CCC), systematically proposed the concept of big data, which was quickly recognized by experts and scholars all over the world. In 2009, American government established the Data.gov website, and allowed the public to mine and use government data for more than 44,500 data sets on the website. Many new products were born, such as flight punctuality rate query, and so on. This move has aroused widespread concern around the world, and Kenya, Britain and other countries followed closely and opened their government's data gates. In 2012, the Davos Economic Forum in Switzerland further affirmed the application value and development prospects of big data. In March 2012, the White House released the Big Data Research and Development Initiative, and provided more than \$200 million to develop information acquisition and mine analysis tools for massive data. This initiative marks the advent of the big data age.

TABLE I. DOCUMENTS RELATED TO BIG DATA IN CENTRAL GOVERNMENT

\begin{tabular}{|c|c|c|}
\hline Date & Name & Key points of document \\
\hline 2015.7 & $\begin{array}{l}\text { Several Opinions on Using Big } \\
\text { Data to Strengthen Service and } \\
\text { Supervision of Market Entities }\end{array}$ & $\begin{array}{l}\text { Clarify the timetable for } \\
\text { the application and } \\
\text { development of big data }\end{array}$ \\
\hline 2015.7 & $\begin{array}{l}\text { Guidance on Actively } \\
\text { Promoting the "Internet +" } \\
\text { Action }\end{array}$ & $\begin{array}{l}\text { Straighten out } \\
\text { relationship between } \\
\text { data and Internet+ }\end{array}$ \\
\hline 2015.8 & $\begin{array}{l}\text { Platform for Action on } \\
\text { Promoting the Development of } \\
\text { Big Data }\end{array}$ & $\begin{array}{l}\text { Propose that boost } \\
\text { industrial innovation with } \\
\text { big data }\end{array}$ \\
\hline 2016.6 & $\begin{array}{l}\text { Guidance for Promoting and } \\
\text { Regulating the Development of } \\
\text { Health Care Big Data } \\
\text { Application }\end{array}$ & $\begin{array}{l}\text { Promoting the application } \\
\text { of big data technology in } \\
\text { medical and health field }\end{array}$ \\
\hline 2016.8 & $\begin{array}{l}\text { Notifications on Organizing } \\
\text { and Reporting Special Project } \\
\text { of Innovation Capacity } \\
\text { Construction in Big Date }\end{array}$ & $\begin{array}{l}\text { Implement special project } \\
\text { of innovation capacity } \\
\text { construction in big date }\end{array}$ \\
\hline 2016.12 & $\begin{array}{l}\text { Development plan for Big Data } \\
\text { industry (In 2016-2020) }\end{array}$ & $\begin{array}{l}\text { Enhance the innovation } \\
\text { and development capacity } \\
\text { of big data industry }\end{array}$ \\
\hline
\end{tabular}

In recent years, big data technology in China and its related applications have developed rapidly. In December, 2011, Ministry of Industry and Information Technology issued Twelfth Five-Year Development Plan for Internet of Things, and proposed to develop massive information storage and processing, and information technologies such as data mining, image and video intelligence analysis. Although this plan does not explicitly propose the concept of big data, the above information technologies are important parts of big data technology. China first mentioned the concept of big data in 2014 Government Work Report. The Report clearly pointed out that we must surpass the advanced in the next generation of mobile communications, big data, and advanced manufacturing. The central government attaches great importance to the application and development of big data. From 2014 to 2017, the concept of big data has appeared in the Government Work Report for four consecutive years. The 2015 Government Work Report made it clear that we should promote the integration of mobile Internet, cloud computing, big data, and the Internet of Things with modern manufacturing. The 2016 Government Work Report proposed to promote the widespread use of big data, cloud computing, and the Internet of Things. The 2017 Government Work Report proposed to further advance the "Internet + " initiative and the national big data strategy. At the same time, the central government paid high attention to the top-level design of big data development, and issued several documents, as shown in "Table I".

\section{THE INFLUENCE SPACE OF BIG DATA IN THE REFORM OF GOVERNMENT MANAGEMENT}

\section{A. Building An Open Government -- Big Data Promotes Openness of Government Information}

Big data technology is conducive to opening the boundaries between horizontal government departments, and between government and citizens. The information island phenomenon will gradually disappear, and the sharing and disclosure of government data will become possible. First of all, through big data, we can concentrate the data resources of various departments to form a "data cloud" and formulate access protocols and assign access rights, and each department can obtain cloud data within the scope of authority as required. This way breaks the constraints of the original time and space, and improves the efficiency of data sharing. Next, the open and shared platform of governmental information based on big data is conducive to building a sunny government and promoting innovation. Big data makes the administrative process more open and transparent. The public can monitor government behavior in real time, and urge public officials to improve their work efficiency, so that violations of laws and regulations such as "behind-the-scenes deal" and "black box operation" are nowhere to hide, and rights will be exercised in the sun. The opening of government data to enterprises and the public will inspire the innovative potential of social forces and provide good conditions for innovation. Finally, big data technology helps to standardize data storage standards of government departments, weaken the thinking of individual politics, and enhance data consistency across departments[3]. On this basis, the established government intelligence system can effectively solve the data conflicts or contradictions between government departments.

\section{B. Building A Service-Oriented Government -- Big Data Drives the Refinement of Public Services}

"Great undertakings have small beginnings". In the past, the public service of the government is the same to everyone, and because of the limitation of technology, it was difficult to refine the management according to the characteristics of different people. With the continuous development of the economy and society and the increasing improvement of living standards, people's demands are constantly upgrading. The public are no longer satisfied with passive acceptance of services, but want to choose personalized public services that meet their own requirements. Therefore, the refinement of government public services will become increasingly important. Characterized by accuracy, comprehensiveness, efficiency, and intelligence, big data technology has restored "human universality" to "human speciality", which can meet the individual needs of the public and provide technical 
support for the government's public service refinement. Taking refined traffic management as an example, traffic congestion problem is a typical symptom of "urban disease", and seriously disturbs the daily life of urban residents. Big data provides a traffic management mode that is small in cost, quick in effect and in line with the wishes of citizens, which is to improve the traffic use efficiency by designing the transportation organization scheme (including traffic intersection control, traffic signal timing) scientifically. This mode must be refined, and it requires to adjust the traffic management strategy quickly and reasonably based on the real-time and comprehensive road condition information of the city. Obviously, manpower is unable to complete such work, while the intelligent traffic management systems based on big data provide the possibility for refined management. Another example is the refined service for the aged. The aging population in China is accelerating, and the nursing home model is difficult to be widely recognized by the elderly, which puts forward higher requirements for the social pension service. The leading problem is how to measure the health of the elderly in time without the care of the staff. Wisdom pension service based on big data provides a feasible path for the family-centered and community-based refined householdsupporting pattern. When the elderly do exercise, they can wear smart shirt, smart shorts, smart belts, smart watches and other equipment to monitor their heart rate, pulse, breath, body temperature, blood pressure and other vital signs in real time. When the elderly are in bed, the smart mattress can be used to monitor their vital signs. In the event of an abnormality, the community health service center will make judgments on the condition of the elderly and take corresponding medical measures. Moreover, the application of big data to promote the government public service refinement also can be used to public security, public health, food safety, population management, and other fields. The wide application and comprehensive coverage of this mode will meet the individual needs of citizens and improve the public management capability of the government.

\section{Building An Efficient Government -- Big Data Helps Governments Make More Precise Decisions}

Decision-making is the core of government management, and decision making capacity determines the success or failure of the government's public management. Data and information are the basis for decision making and relate to the accuracy and scientificity of decision making. The traditional way of government decision making collects information through symposiums, hearings, and citizen opinions. Strictly speaking, these information is small-scale sample survey data, and is not comprehensive. These data make government decision-makers only have a glimpse of part of them but not all of them, so the decisions made inevitably produce deviation. Big data technology abandons traditional decision making methods such as sample survey and experience-based judgment, and makes an analysis with complete and comprehensive information by using data fusion, data mining, intelligent computing and other technologies, so the decision scheme is more scientific and reasonable. As Daniel C. Esty, a famous American scholar, said: "the judgment of any elite or interest group is one-sided. Only by believing in big data technology based on the overall analysis can the government make the right decisions and improve its management efficiency"[4-7]. "Let data do the work", which often brings results beyond the scope of our experience. For example, through big data analysis, it is found that the linear dependency between financial income and registered capital of enterprises in China is as high as 0.987 , which indicates that the relaxation of enterprise registration policy can increase fiscal revenue. Big data technology transforms fuzzy decision making into precise one, and increases the scientificity of decision making. Big data technology collects, analyzes and processes information in real time, ensuring the timeliness of decision-making. This has made the static government decision-making dynamic and greatly improved the efficiency of decision making. In a word, big data technology can make full use of government-owned information resources to provide guarantee for the scientificity of government decision-making.

\section{CONCLUSION}

The application of big data has brought about tremendous changes to public management and public services, and also provided a technical path for innovation and improvement of capacity of government management. The full development and utilization of big data technology will help to open the boundaries between horizontal government departments, and between government and citizens. The information island phenomenon will gradually disappear, and the sharing and disclosure of government data will become possible, which will promote the openness of government information and the construction of open government. Characterized by accuracy, comprehensiveness, efficiency, and intelligence, big data technology has restored "human universality" to "human speciality", which can meet the individual needs of the public, provide technical support for the government's public service refinement, and promote the refinement of public services and build a service-oriented government. Big data technology abandons traditional decision making methods such as sample survey and experience-based judgment, and make an analysis with complete and comprehensive information by using data fusion, data mining, intelligent computing and other technologies, so the decision scheme is more scientific and reasonable, which helps governments make more precise decisions and create clean work. Through the above-mentioned methods, big data technology has greatly improved the efficiency and effectiveness of government management, further lowered government operating costs, and comprehensively improved the government's social governance capabilities.

\section{REFERENCES}

[1] Viktor Mayer-Schonberger, Kenneth Cukier. Big Data:A Revolution That Will Transform How We Live, Work, and Think [M]. Zhejiang People's Publishing House; 2013.34-47.

[2] Ping Jian. The Innovation Path Choice of Smart City under the Background of Big Data - A Case Study of Liaoning [J]. Journal for Party and Administrative Cadres, 2016, (01): 42-48.

[3] Han Zhenyan, Fei Chang. Opportunities, Challenges and Countermeasures for the Construction of Public Policy Issues in the 
Age of Big Data [J]. Journal of Hubei Administration Institute,2016, (06): $56-60$.

[4] Li Zhigang. Big Data: Great Value, Great Opportunity, Great Change [M]. Publishing House of Electronics Industry, 2012.

[5] Wang Linxia. On the Improvement of Government Governance Capability in Big Data Era [J]. Public Administration \& Law; 2017 (9). 11-16.

[6] Chen Tao, Li Mingyang. Research on the Construction Strategy of Data Open Platform - Taking the Construction of Wuhan Municipal Government's Data Open Platform as An Example [J]. E-Government, 2015, (07): 46-52.

[7] Wu Min. Open Data in the United Kingdom and the United States Government Application and Implications [J]. Library and Information, 2012, (01): 127-130. 